\title{
Business Cycles and Insurance
}

\author{
by Elmar Helten *
}

\section{Initial remarks}

The relationship between business cycles and insurance in Germany since 50 years has been followed up, whereas market research finally dates back to Joseph's interpretation of Pharao's dreams and thus stands in a 4000 years old tradition.

The turns in the market, the cyclical fluctuation in business between prosperity and depression and its economic motives have always affected the interests, nevertheless the forecast of today's business oracles do not reach up to the precise prognostications of Joseph of Egypt.

That is why market research is considered very sceptically by many practitioners. Whether you share this scornful opinion or whether you not, I leave to your own judgement.

\section{Object of the study}

In the following study we only intended to confront some macro economical time series of the Federal Republic of Germany with some time series taken from the insurance market.

The confrontation of these time series allows the derivation of some so called "ad-hoc hypotheses" on the coincidental trend of the macro economical and the insurancal development and their leading and laging indicators.

It allows furthermore the comparison with theories compounded by insurance economists before the 2nd world war.

The investigated time series were only described and for the present no detailed statistics analyses have been undertaken; just as no prognosis was derived from the diagnosis of the time-series.

\section{The background of the study}

Risk theory supposes the stochastic nature of the claim events. Purely stochastic claims are told to be insurable. If this thesis is correct, for a fair calculation, the insurance company needs information about the random distribution of the claim processes.

On our research on such distribution functions, we (HELTEN, STERK) considered, that the claim processes are interfered by various systematical and statistical errors.

* Professor of Insurance and Business Administration, University of Mannheim. 
One of the a posteriori best known influence factors is inflation, another influence factor, which is very difficult to cover, is the reserve policy of the insurance policy. Business cycles seem to be the third influence factor. In order to testify this assumption empirically, we intend to investigate the dependence of the claim processes from business cycles. This is done separately for various branches of insurance.

\section{Method of investigation}

In the following business cycles are interpreted as sequences of growth.

This is, however, not to be regarded as a comment on the question, whether the limits to growth are reached or not.

Nevertheless in the Federal Republic of Germany the real gross national product since 1951 has always increased (except for 2 years, 1967 and 1975, see the lower turning points).

If $x_{1}, x_{2}, \ldots, x_{t-1}, x_{t}, x_{t+1}$ is the original time series, the business cycles are described by the growth rate

$$
w_{t}=\frac{x_{t}-x_{t-1}}{x_{t-1}}
$$

The growth rates dispose of the great advantage of having no dimension. Thus we may neglect the absolute scale of the series and only regard the relative increase.

\section{Business cycles in the Federal Republic of Germany after the 2nd World War}

In the years between 1949 and 1975 in Germany we can distinguish 6 business cycles (measured upon the real gross national product).

\begin{tabular}{|c|l|l|l|}
\hline \multicolumn{2}{|c|}{ growth cycle } & \multicolumn{1}{c|}{ period } & \multicolumn{1}{c|}{ down swing } \\
\hline \multirow{2}{*}{ 1st cycle } & ca. 1949-1954 & $1949-1950$ & $1951-1954$ \\
& (6 years) & (2 years) & (4 years) \\
2nd cycle & $1955-1958$ & 1955 & $1956-1958$ \\
& (4 years) & (1 year) & (3 years) \\
3rd cycle & $1959-1963$ & $1959-1960$ & $1961-1963$ \\
& (5 years) & (2 years) & (3 years) \\
4th cycle & $1964-1967$ & 1964 & $1965-1967$ \\
& $(4$ years) & (1 year) & (3 years) \\
5th cycle & $1968-1971$ & $1968-1969$ & $1970-1971$ \\
& $(4$ years) & (2 years) & (2 years) \\
6th cycle & $1972-1975$ & $1972-1973$ & $1974-1975$ \\
& (4 years) & (2 years) & (2 years) \\
\hline
\end{tabular}

The lower turning points : 1954, 1958, 1963, 1967, 1971, 1975.

The upper turning points : 1951, 1955, 1960, 1964, 1969, 1973. 


\section{Leading, laging and coincident Indicators}

The growth rate of the nominal gross national product (pict. 1), that of the private consumption (pict. 2) and that of the total investments (pict. 3) are coincident indicators for the real gross national product.

Picture 4 demonstrates the decrease and increase of the total investments, specified as national investments, investments for housing, assets. The assets are of great importance for the growth of machinery and assembling insurance. It follows, that the growth rate of the assets can be considered as leading indicator. This quality would be accentuated even more if you compared 3 month's rates instead of year's rates.

The cycle of the quota of unemployed takes the contrary course (pict. 5).

\section{Llfe insurance and business cycles}

The contributions received by German life insurance companies during the last 25 years have increased more than the national income (pict. 6). It is obvious, that the growth rates of the national income are nearly coincident with the growth rates of the income of employment (pict. 7) and that of the disposable income of the private households. As the income of employment includes social insurance, we prefer the term of the disposable income of the private households (pict. 8).

The amplitudes of the growth cycles of the disposable incomes, however, are smaller than those of the national income.

The growth rates of the total of insurance amounts (pict. 9) demonstrate just as much the dependence of life insurance from business cycles. This coincidence is particularly significant for the growth rates of the insurance amounts of the new business (pict. 10). The development of the cancellation is contrary and increases considerably in the periods of higher unemployed quotas (pict. 11).

The development of life insurance was influenced furthermore by the so called "Befreiungsaktionen" (relief from social insurance contributions) (1957, 1965, 1968) and the fiscal support by the 3rd law of capital formation (1970), the effects of which caused considerable increase in 1970/71.

Without relief actions the growth rate of new business would be more conform to the cyclical trend (pict. 12).

Under elimination of fiscal support and legislatoral actions, it can be demonstrated that the development of life insurance in Germany is nearly coincident with business cycle.

The same is true of the upward and downward movings of the insurance amounts out of new business (pict. 10).

In the thirties, BRAUN recognized cancellation's dependence from the cycles of business. Following her, during the upswing the attractive rates restrain new business, during the downward swing restrictive effects originate with the reduced incomes of private households and the higher unemployment. 
The guaranteed technical rate of interest of $3 \%$ in German life insurance after the 2nd world war, however, was no impediment for new business in life insurance in so far as the high participation in profits - more than $90 \%$ - compensated this market disadvantage.

\section{Health insurance and business cycles}

Any analysis of the dependence of private health insurance from business cycles is complicated. The total insurance production of the private health insurance shows - compared with the nominal gross national product - (pict. 13) a partly coincident, partly contra cyclical trend.

Only the regard on the single benefits as parts of the total insurance production allows to recognize the lagging trend of the growth rate of the illness costs (pict. 14) and the partial insurance (pict. 15) and the anticyclical behavior of the rates of dailyin-hospital benefits insurance (pict. 16). There is no doubt that the cycle of business has a great influence upon the insured person's willingness for illness: During the upswing the employees lightly go sick, for they do not risk notice because of the raided labour market. During the downswing the little self-employers have enough time for a stay in hospital and profit by the daily-in-hospital benefits insurance.

\section{Automoblle insurance and cycles of business}

The growth rates of the premium income of automobile insurance are coincident with the new car registration (pict. 17). Only the great share of the premium for the third party motor insurance in some years will confuse this evidence.

As the premiums of the third party motor insurance are fixed by the government, even necessary increases of the premiums are very rarely granted before elections, whereas after elections the government lightly gives way to excessive increases (compare 1971 ; pict. 18).

The growth rates of the gross loss in automobile insurance rather are coincident with the growth rates of the nominal gross national product (pict. 19).

By a more precise analysis of the third party motor insurance (pict. 20) it became evident, that the average damage is coincident with the business cycle (pict. 21), whereas the development of the loss frequency (pict. 22) depends on the growth rate of the gross road performance of the cars (pict. 23).

The growth rates of the gross damage compensations take a parallel course to the rates of the street accidents (pict. 24).

\section{Fire Insurance and business cycles}

Already in 1927 RIEBESELL tried to find out a relation between the losses of fire insurance and business cycles. The term of "business cycle fires" was coined at that time. 
From the total fire insurance indemnities (pict. 25), however, no uniform business cyclical trend can be ascertained in comparison to the nominal gross national product. It is necessary to separate the insurance indemnities of the industrial fire insurance from the agricultural fire insurance, in order to find out an anti-cyclical movement of the growth rates of the indemnities payed by the agricultural fire insurance (pict. 26).

The growth rate of the premium income of fire insurance (pict. 28) depends on the growth rate of the investments. The growth rate of the premium income produces a time-lag of $1-2$ years, specially evident in the industrial fire insurance (pict. 29).

For the agricultural fire insurance a large coincidence with the growth of the gross national product could be demonstrated (pict. 30).

\section{Transport insurance and business cycles}

The growth rates of the gross losses in transport insurance during the last years of increase of the industrial turnover (pict. 31). It is only the rhythm of the statistical census that conditions a time lag of about one year (pict. 31). In fact the time lag only amounts to half a year.

The growth rates of the gross losses in transport insurance during the last years was coincident with the growth rates of the nominal gross national product (pict. 32).

\section{Machinery and assembling insurance}

In machinery and assembling insurance the growth rates of the gross premiums with a time lag of less than one year follow the growth rates of the production of investment and consumer goods (pict. 33).

The gross losses in machinery and assembling insurance take a parallel course to the business cyclical trend, indeed with a time-lag of about one year, which can be explained by the duration of the loss investigation and assessment (pict. 34).

\section{Concluding remarks}

In order to learn from the relations between business cycle and single branches of insurance, we should not only analyse the kind of their cyclical dependences but also regard the quantitative effects. But already the submitted investigation allows the conclusion, that the oscillations of the claims not always are random but to a large degree cyclical.

Whether it will be possible to use leading business indicators for the forecast of premium income can not yet be proofed for sure. Nevertheless the present study suggests the assumption that further investigations in this direction may lead to success. 


\section{REFERENCES}

1. BRAUN, M.S., "Konjunktur und Versicherungswesen", Assekuranz-Jahrbuch, 49, 1930, 79-91.

2. BUEHLMANN, H., Mathematical Methods in Risk Theory, Berlin, Heidelberg, New York, 1970.

3. HELTEN, E., STERK, H.-P., "Zur Typisierung von Schadensummenverteilungen ", Versicherungswirtschaft, 31, 1976, 113-120.

4. LORENZ, P., "Feuerschäden, Niederschlagshöhe und Konjunktur", Neumann's Zeitschrift für Versicherungswesen, 55, 1932, 541-544.

5. MAHR, W., "Die Konjunkturabhängigkeit der Feuerversicherung", Zeitschrift für die gesamte Versicherungswissenschaft, 34, 1934, 43-55.

6. OTTING, A., "Konjunktur und Lebensversicherung", Neumann's Zeitschrift für das Versicherungswesen, 50, 1927, 978-979.

7. RIEBESELL, P., “Konjunktur und Feuerschäden", Neumann's Zeitschrift für Versicherungswesen, 50, 1927, 29-31.

8. SEAL, H. L., Stochastic theory of a risk business, New York, 1969.

9. STOBBE, A., Gesamtwirtschaftliche Theorie, Berlin, Heidelberg, New York, 1975.

10. WAGNER, A., Die Wachstumszyklen in der Bundesrepublik Deutschland. Eine komperativ-dynamische Komponentenanalyse für die Jahre 1951-1970, Tübingen, 1972. 

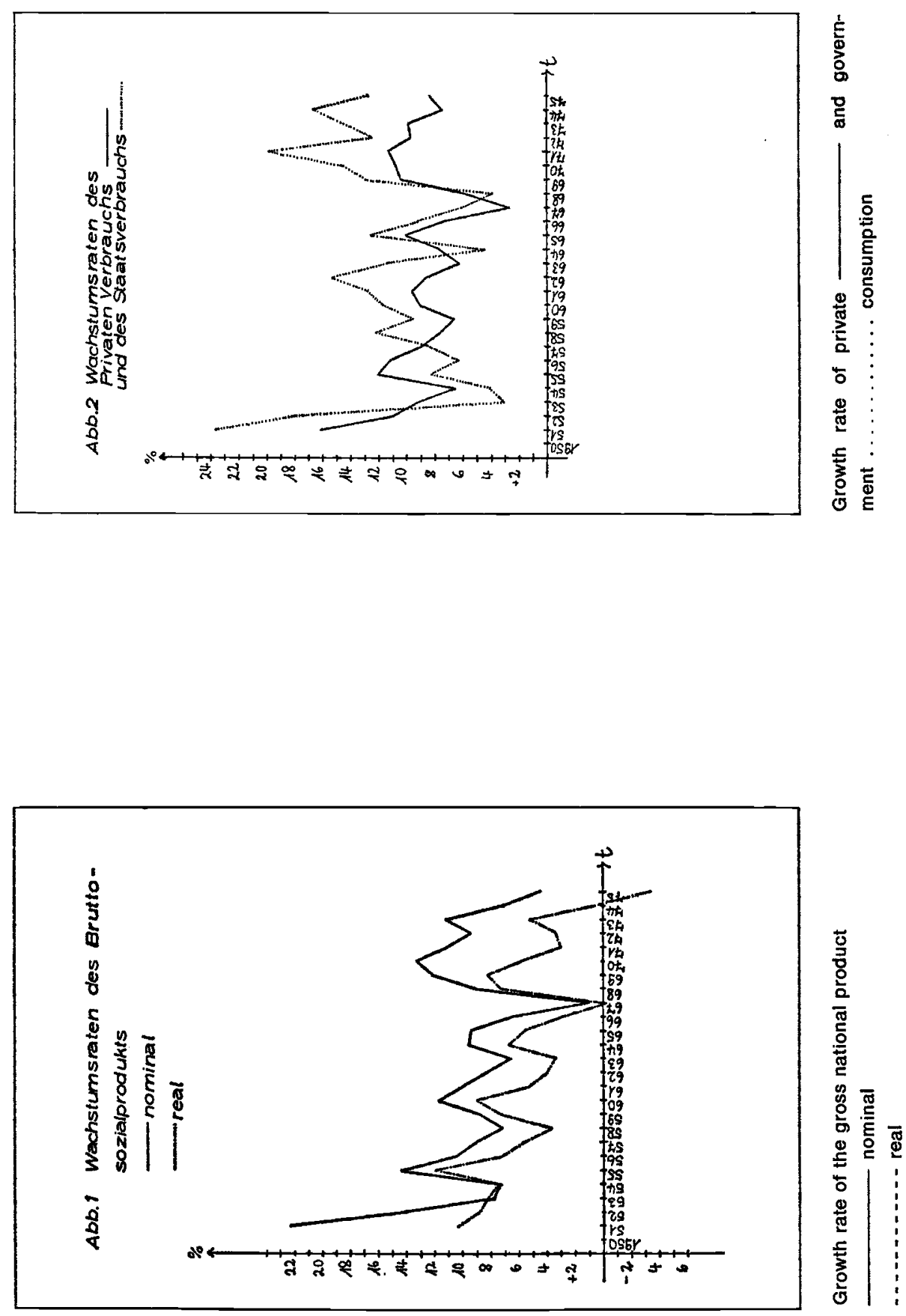


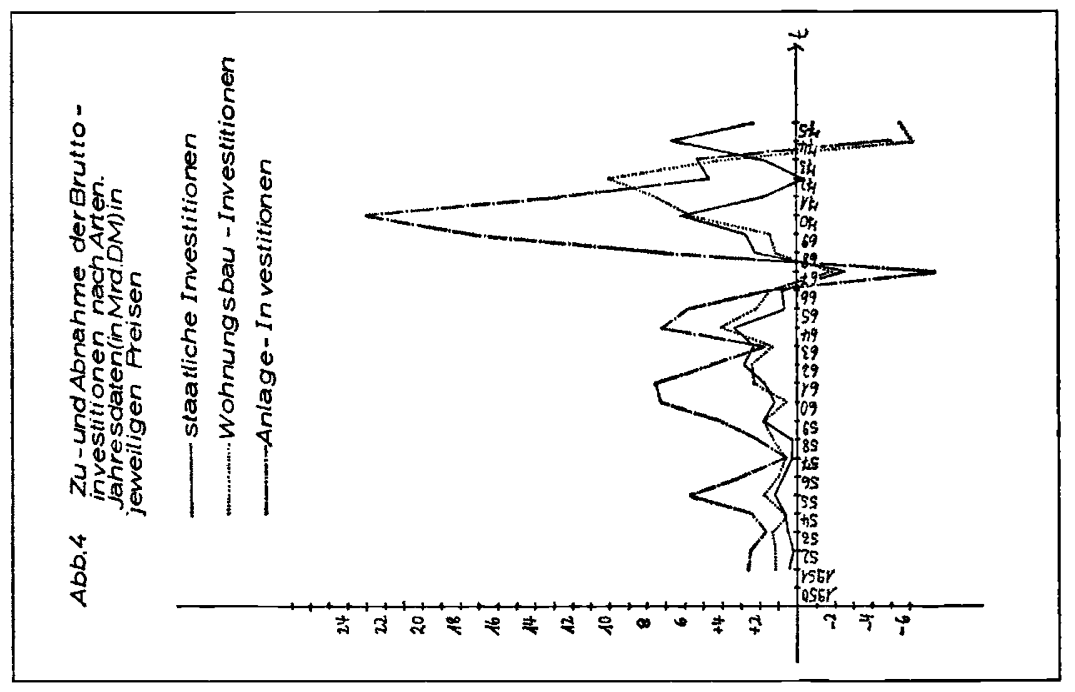

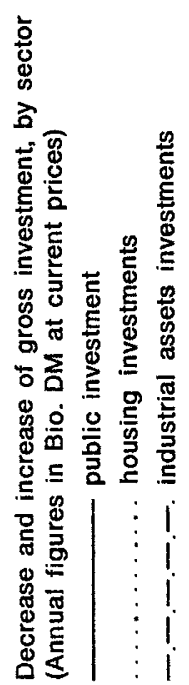

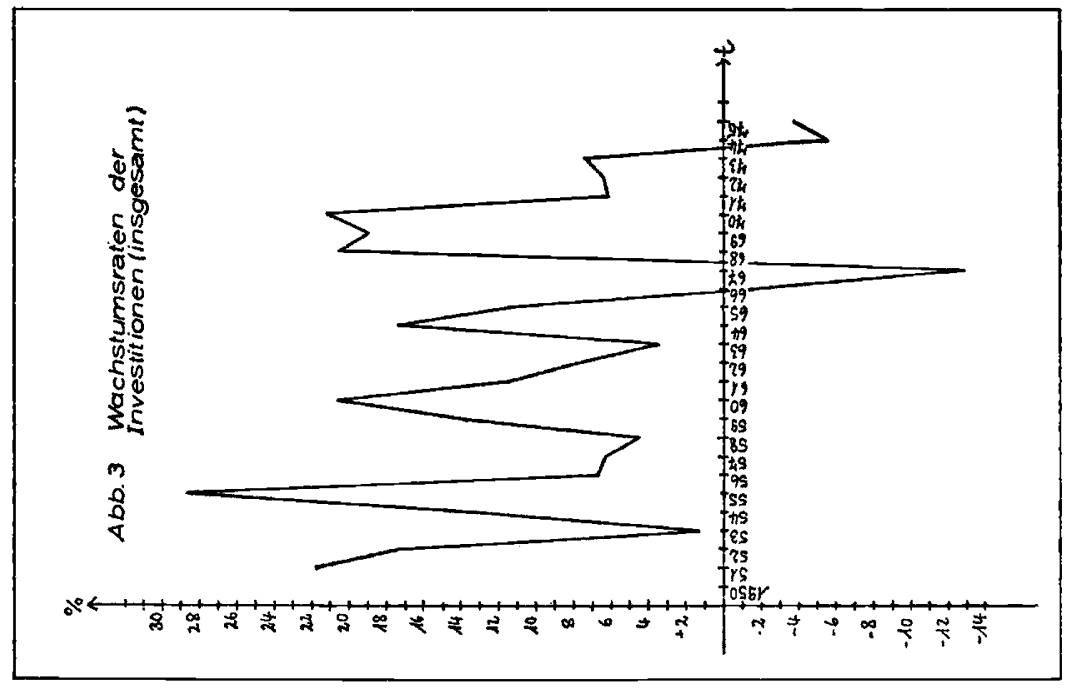

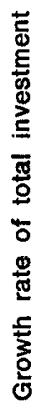




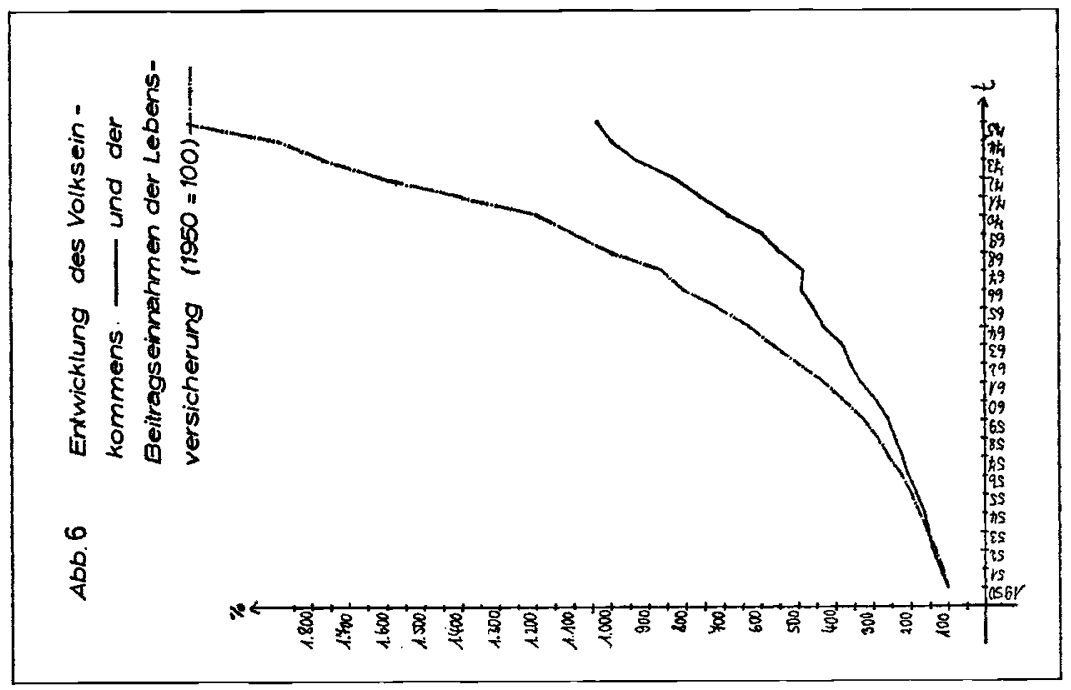

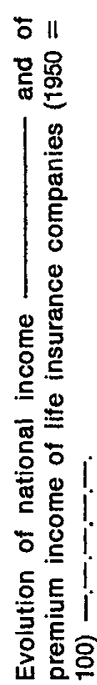

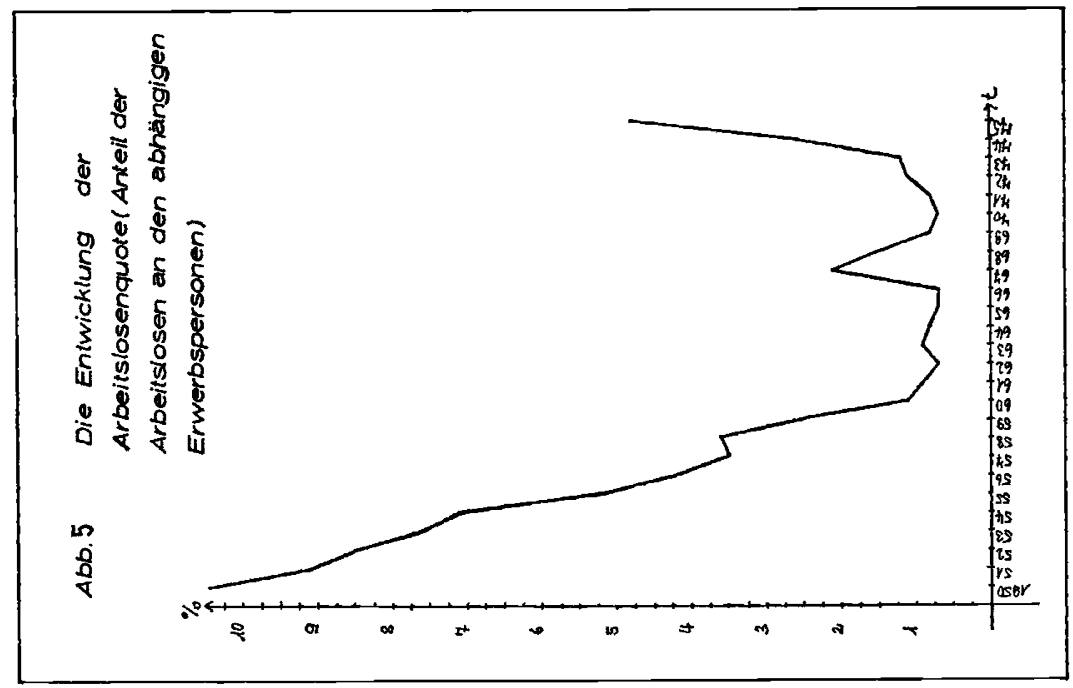

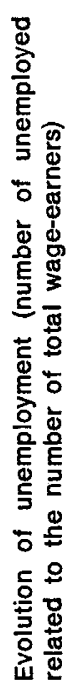



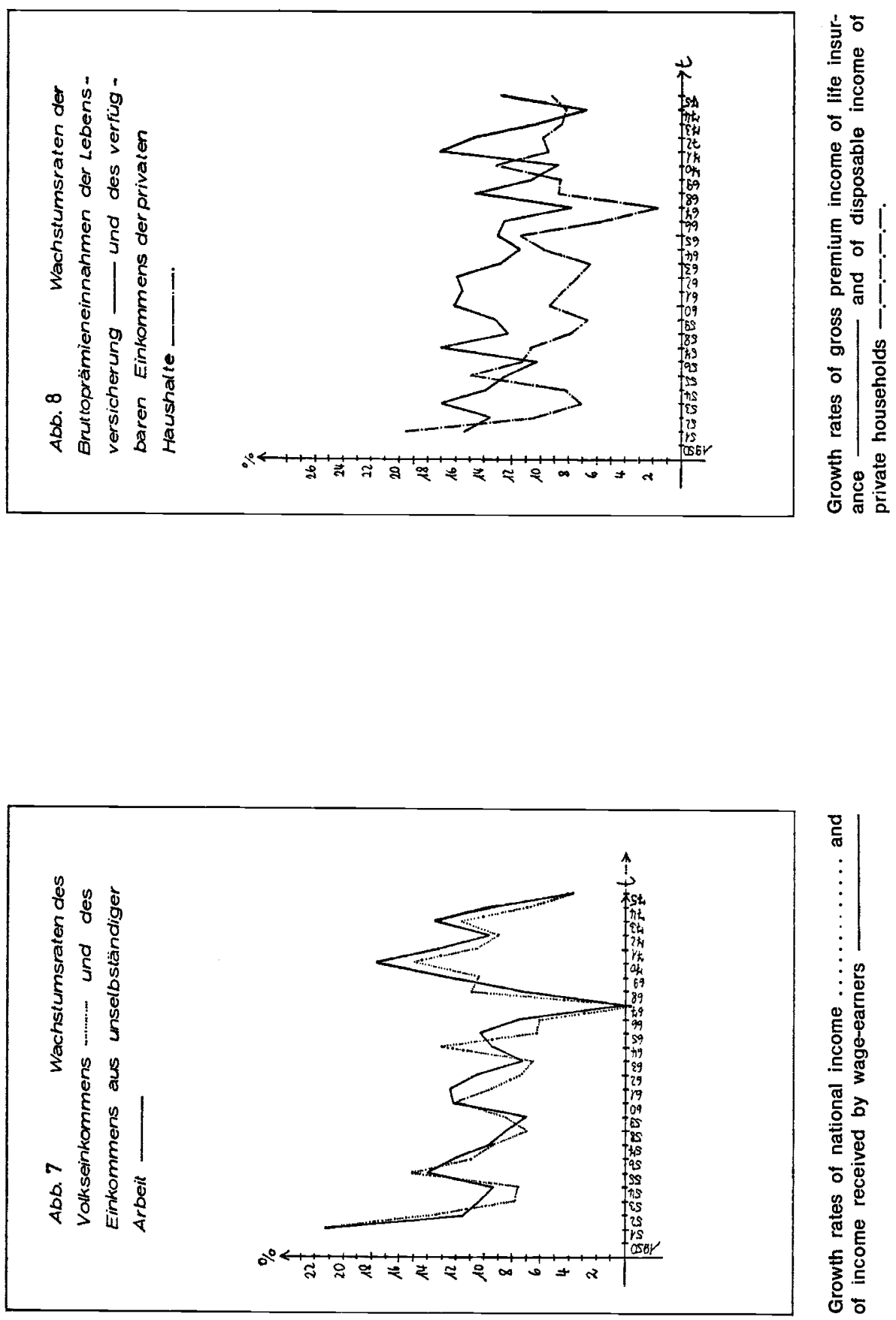


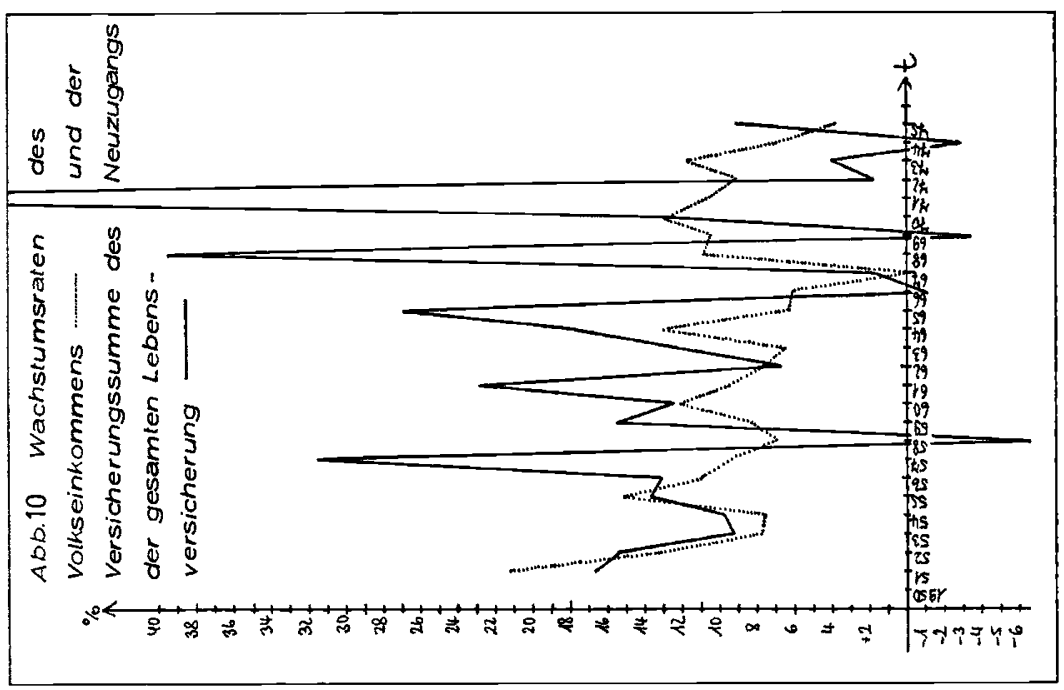

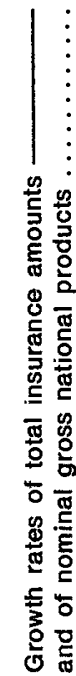

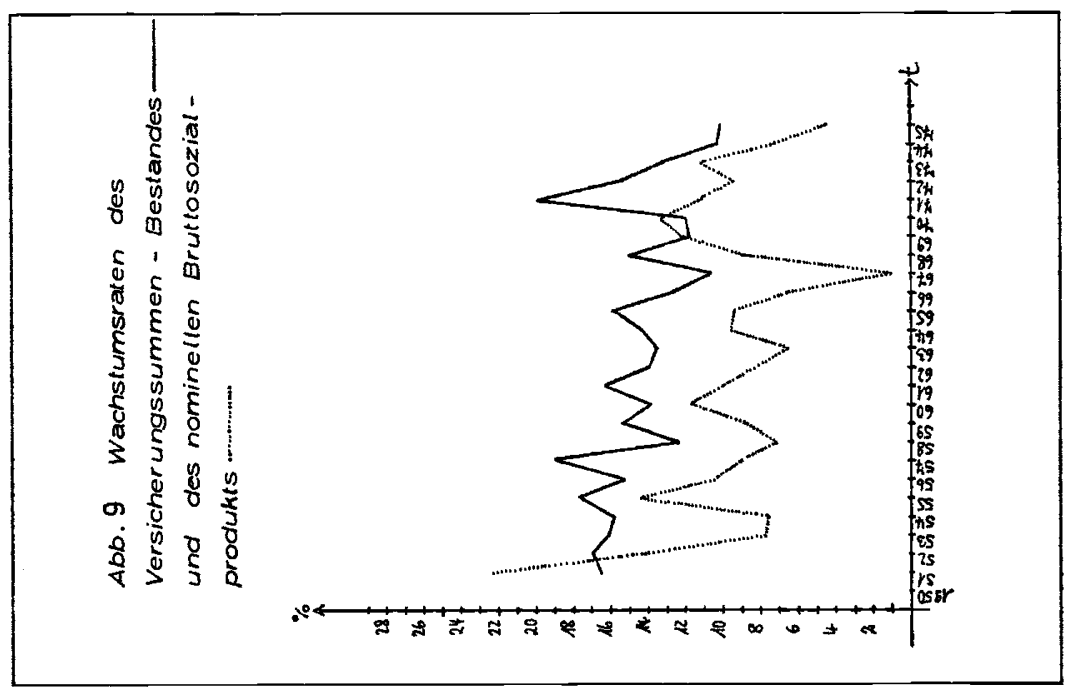

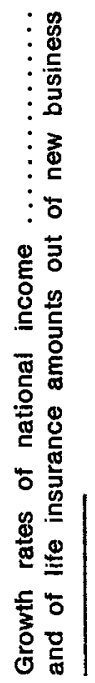




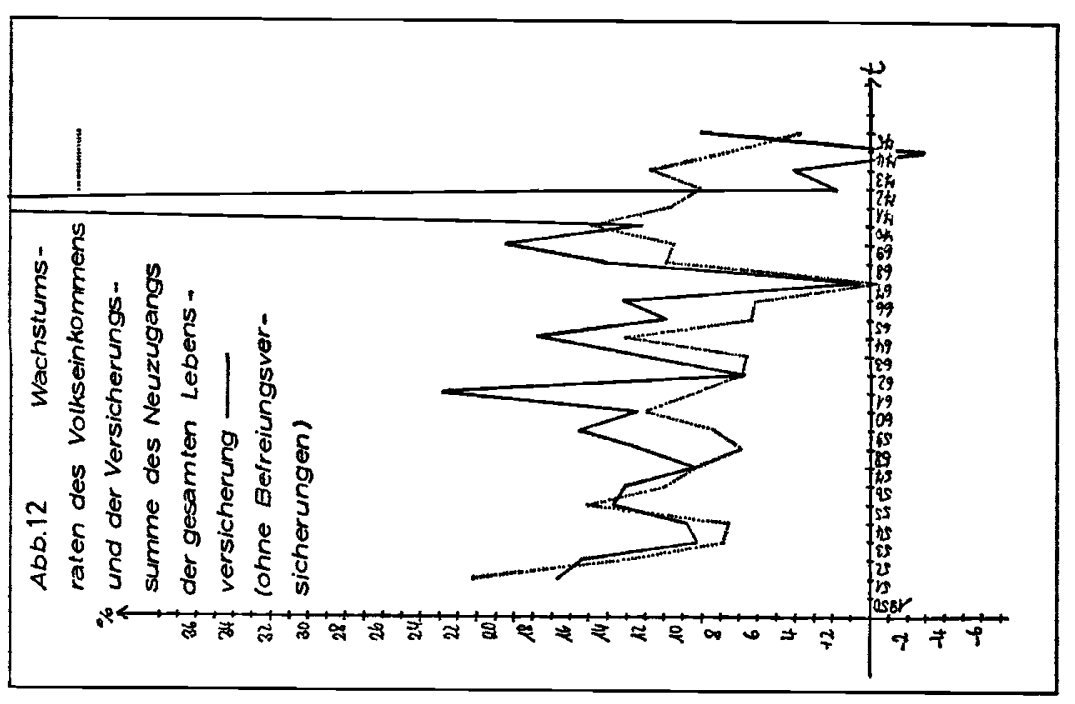

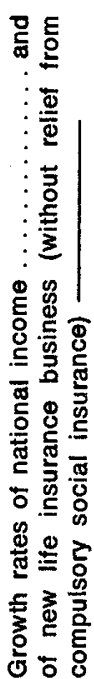

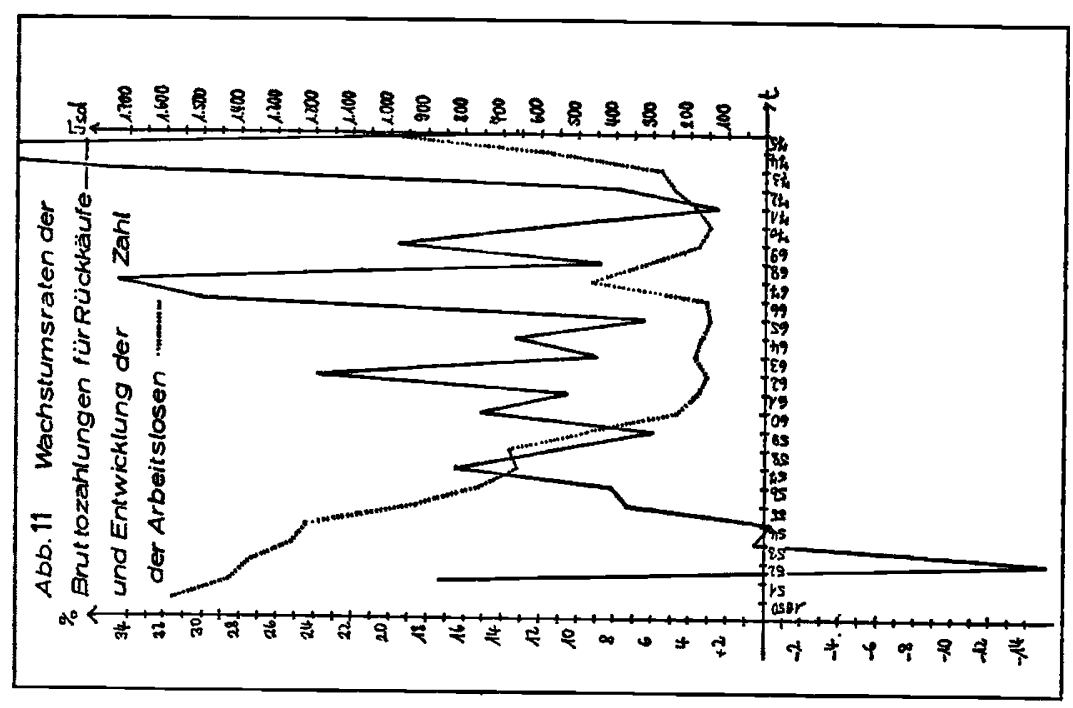

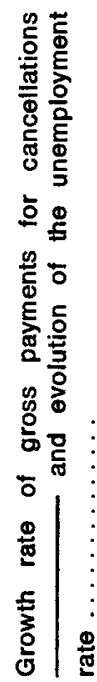



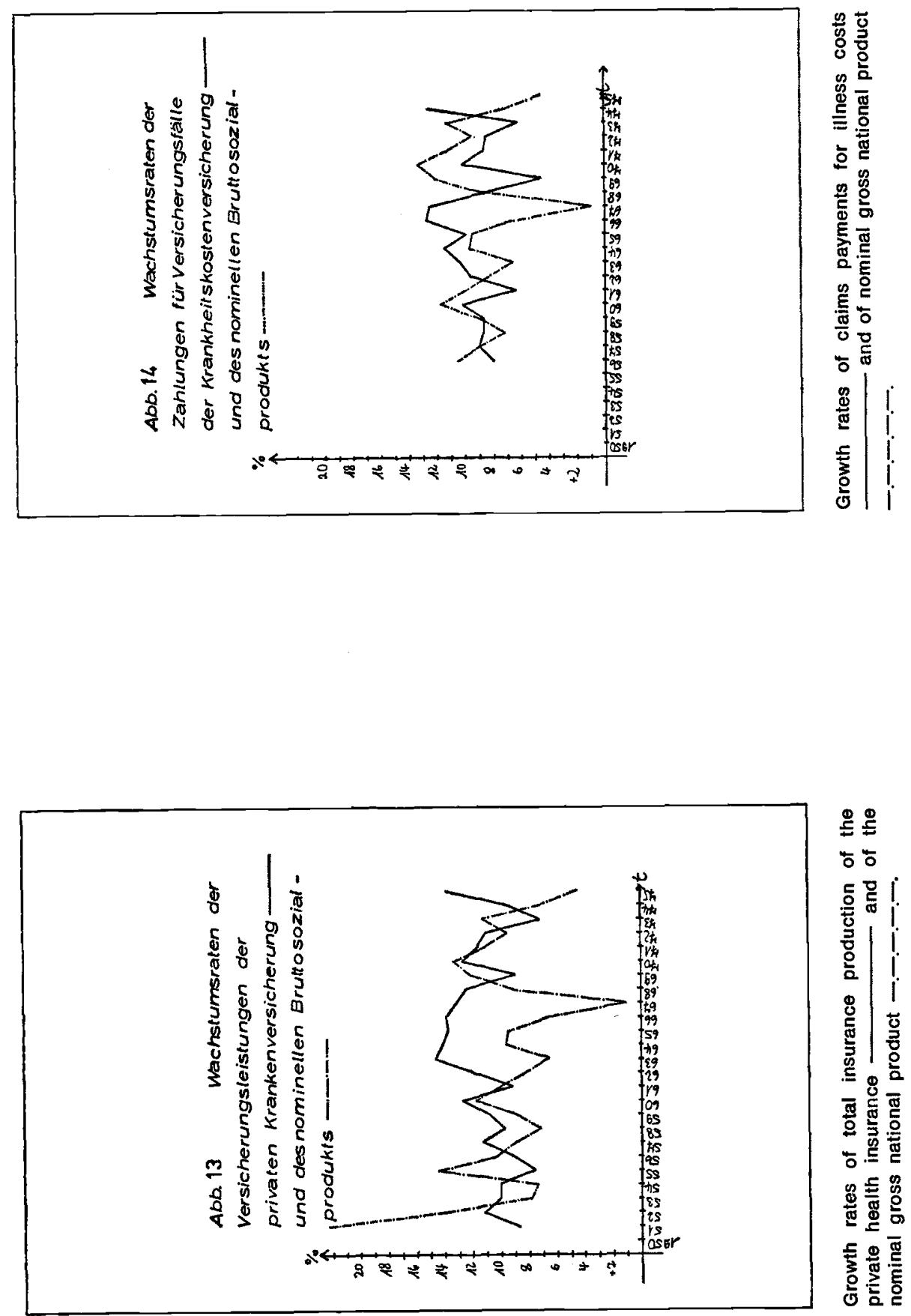

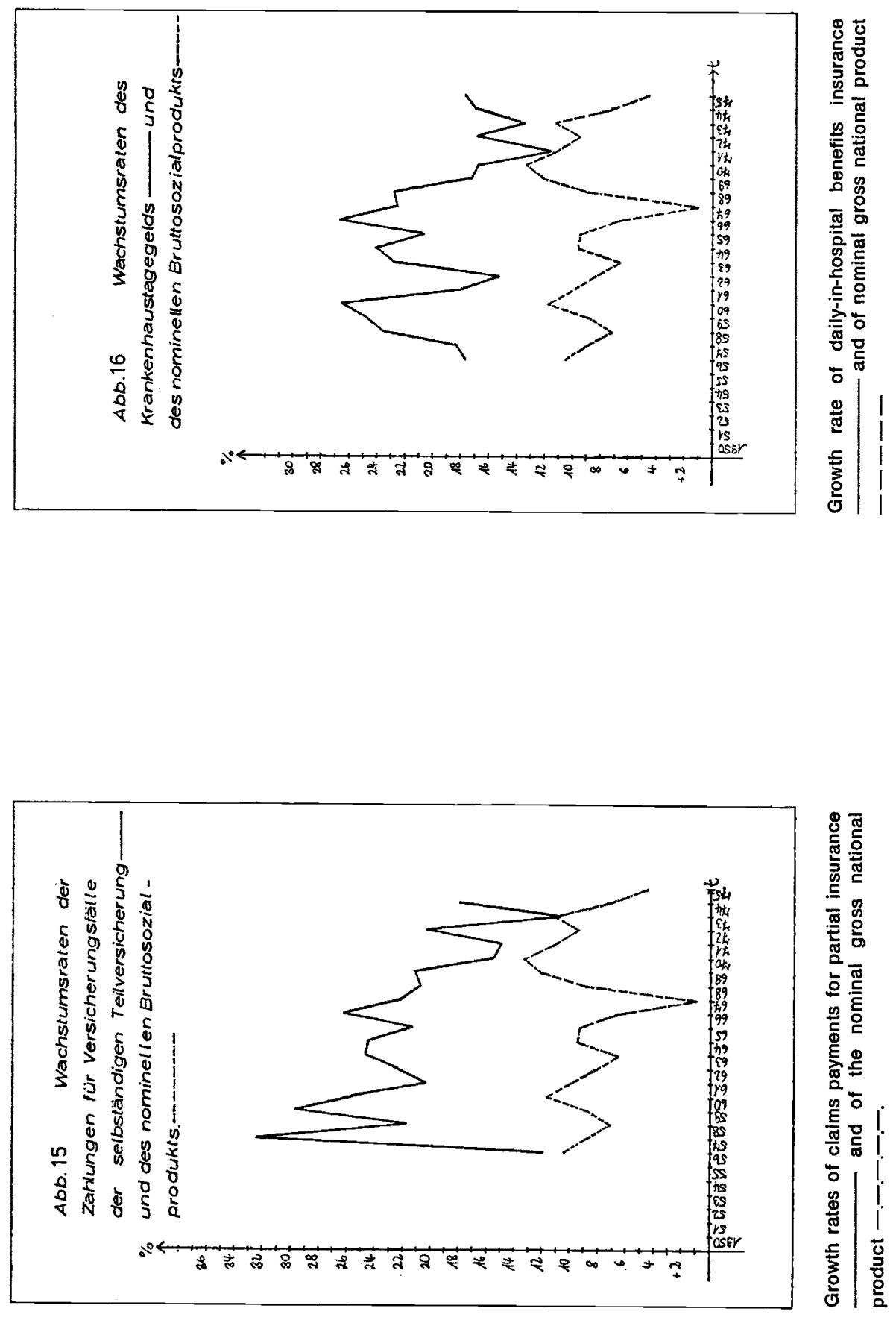

66 

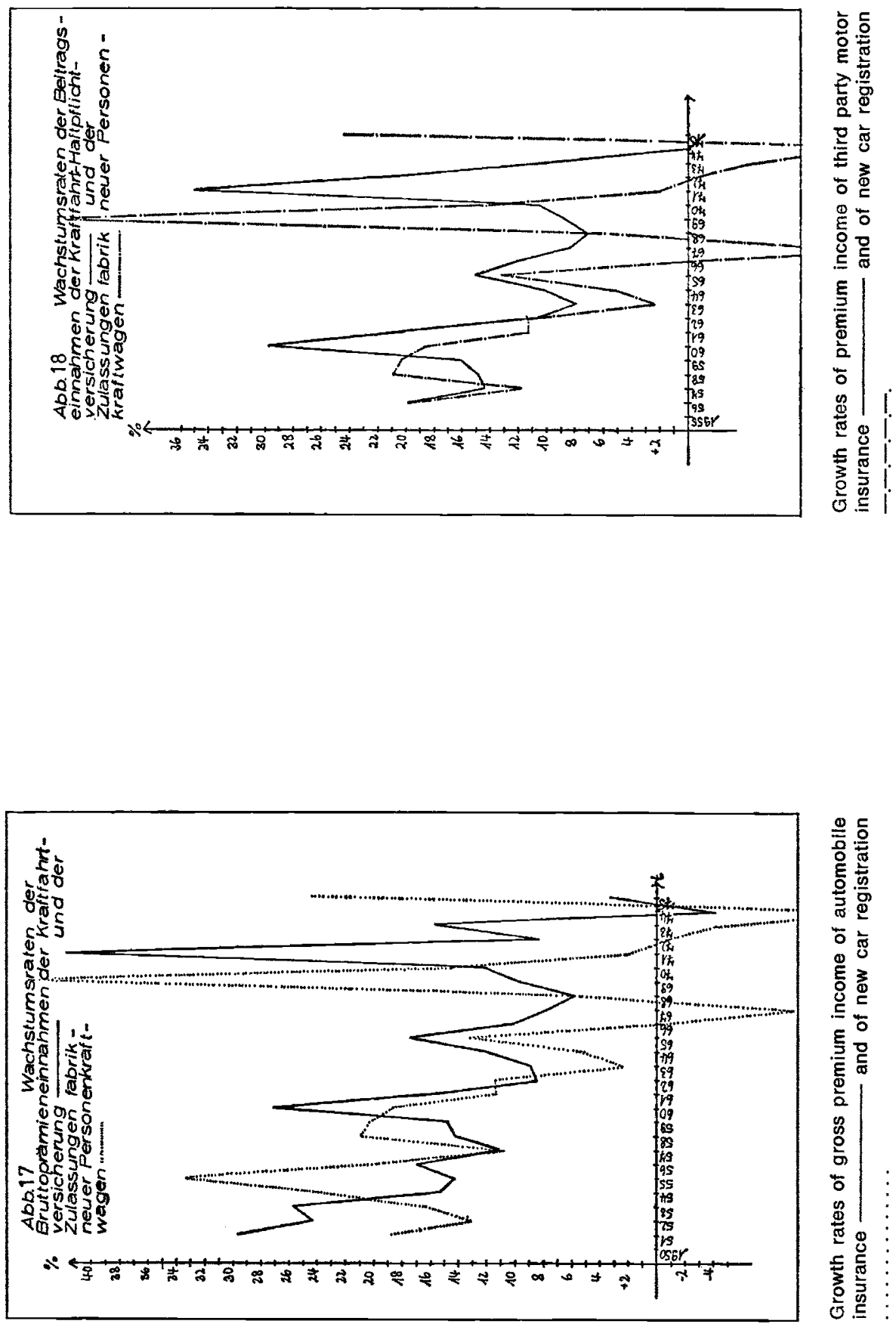


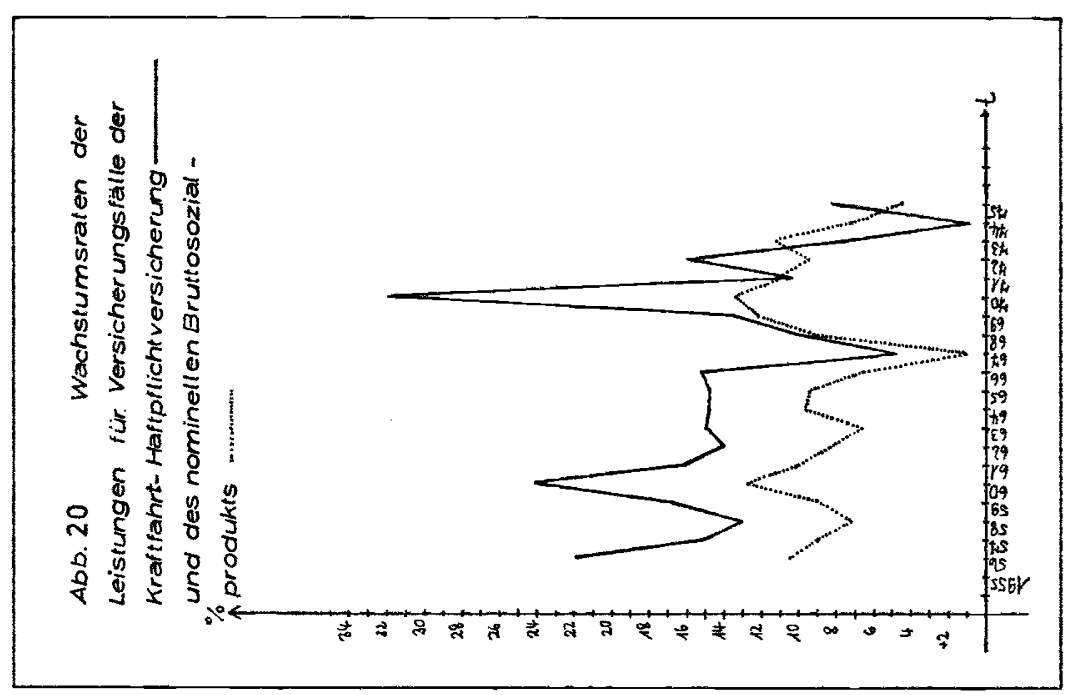

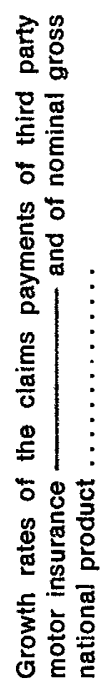
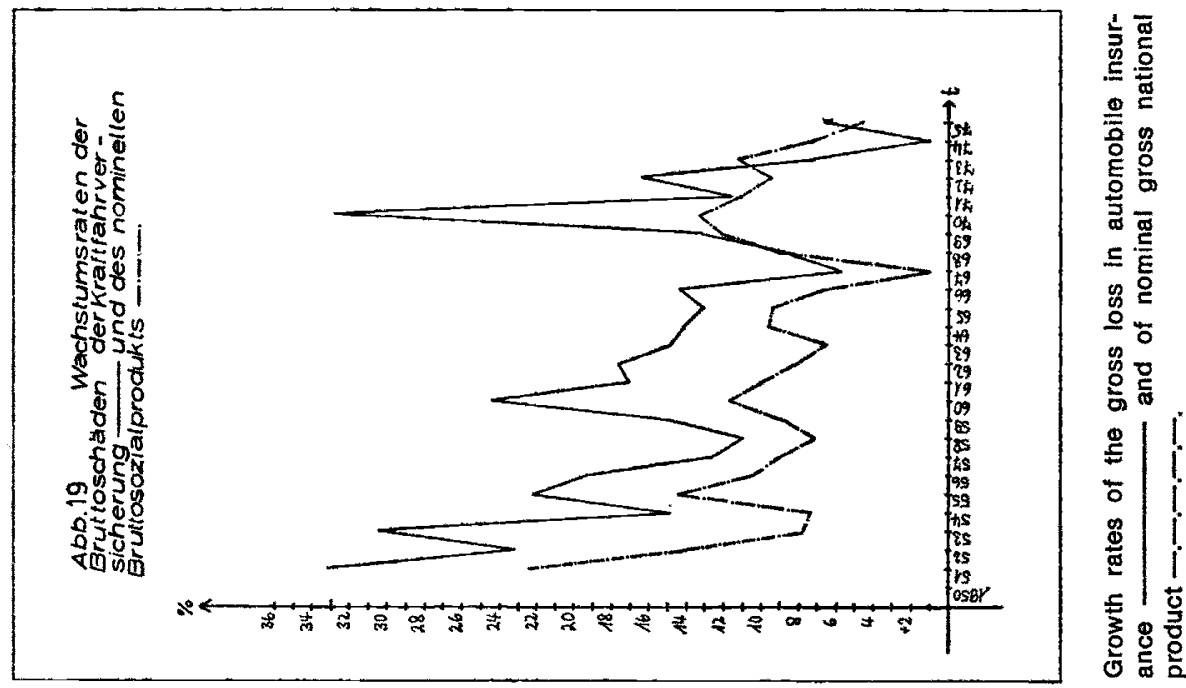

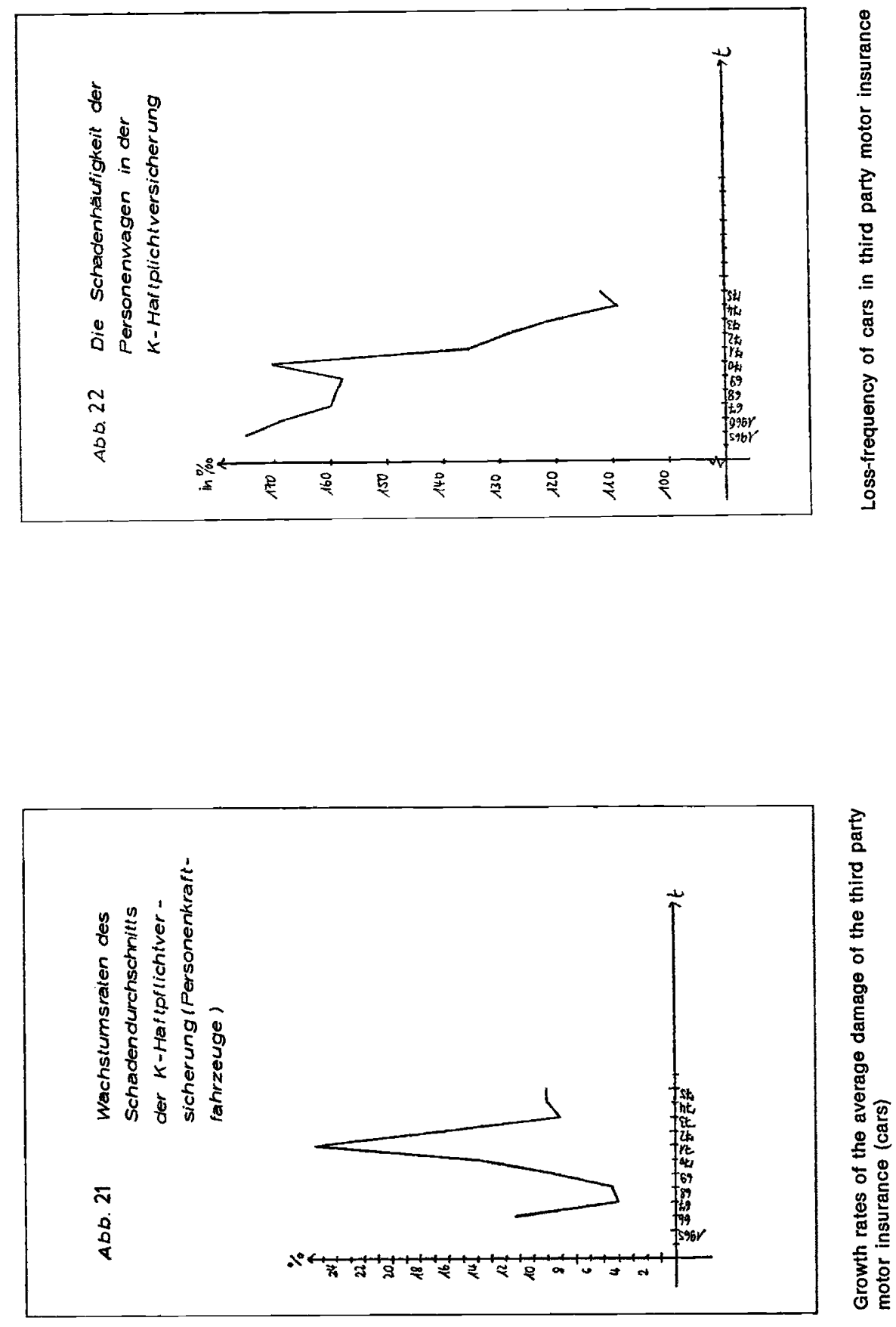

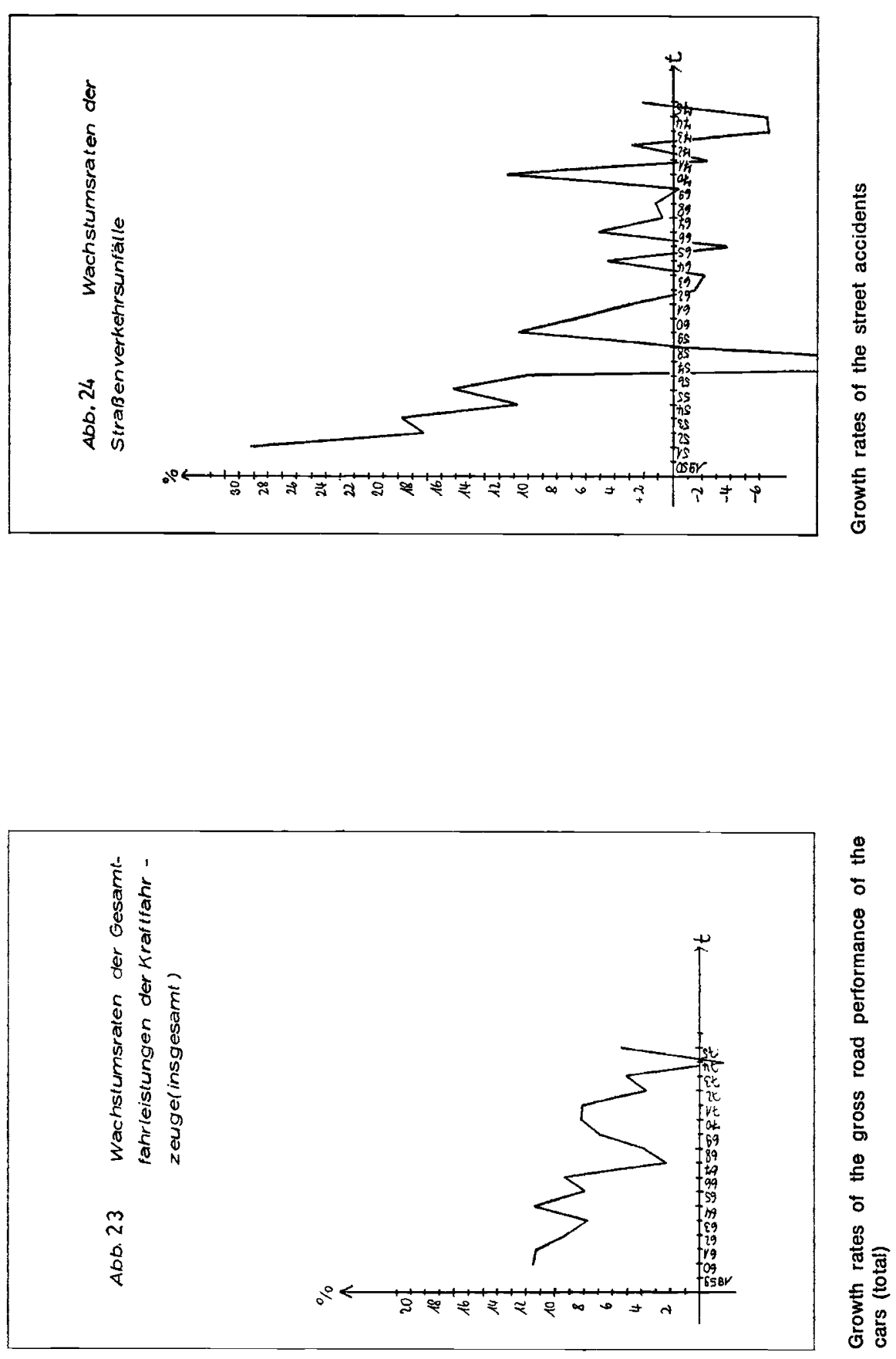

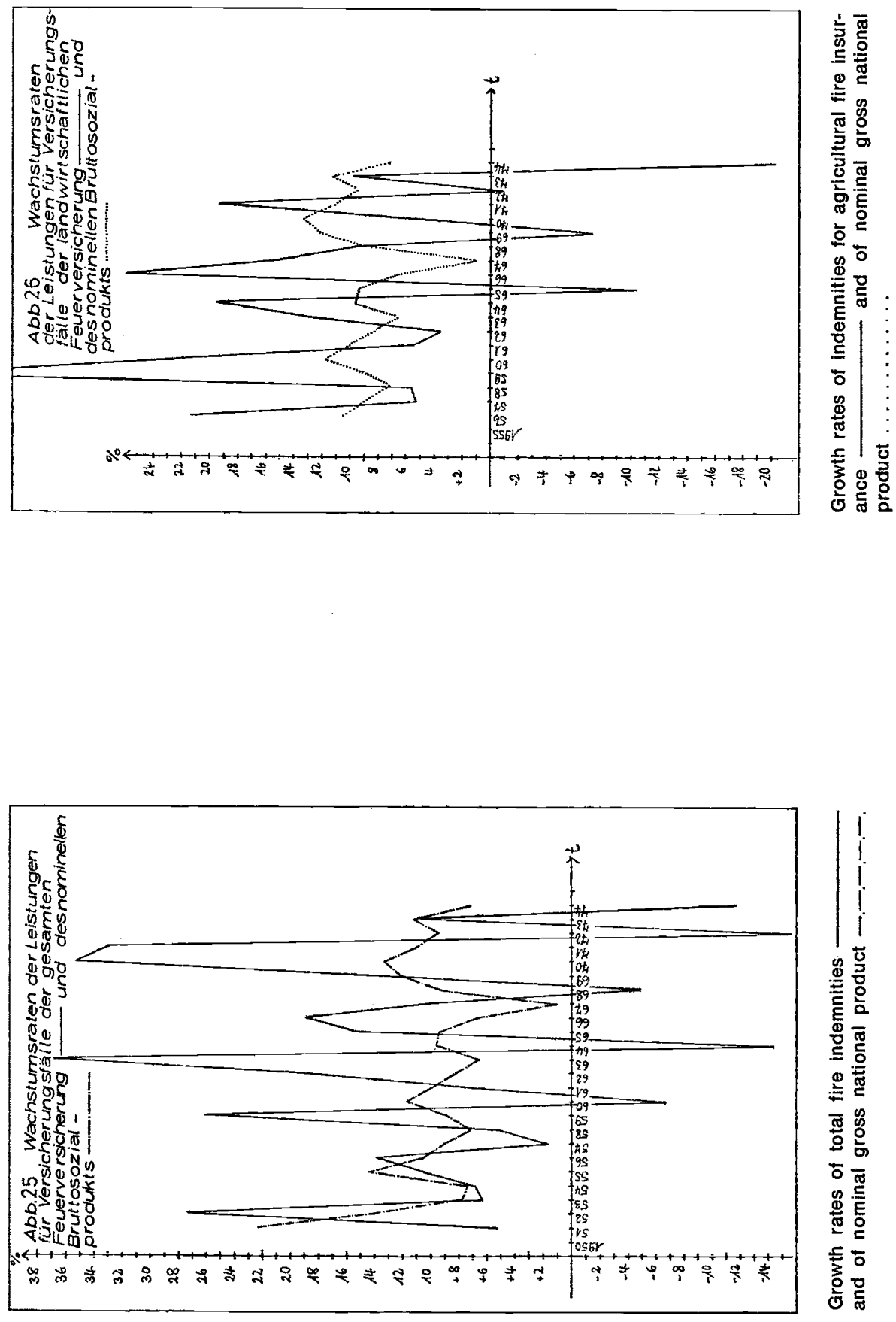

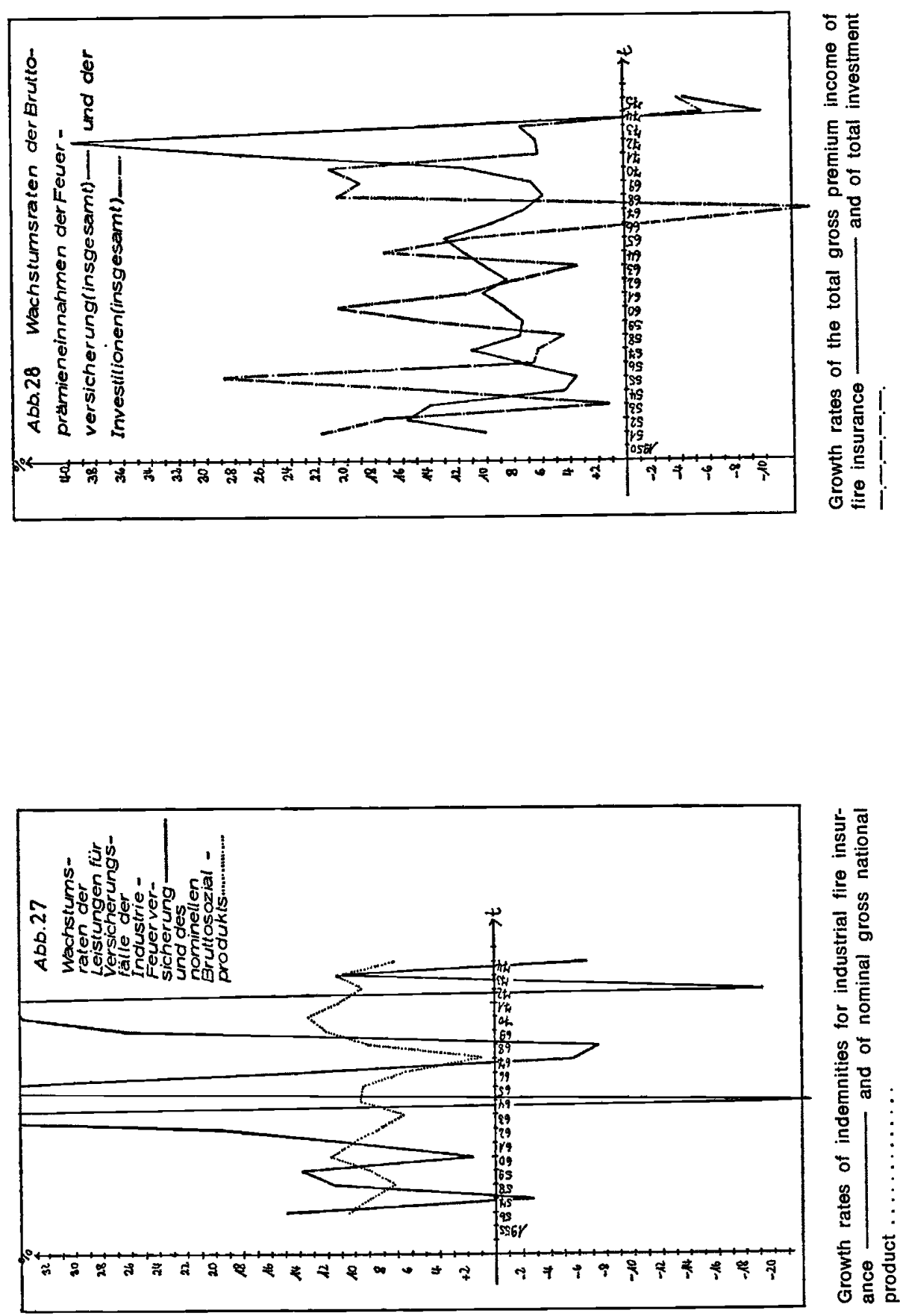


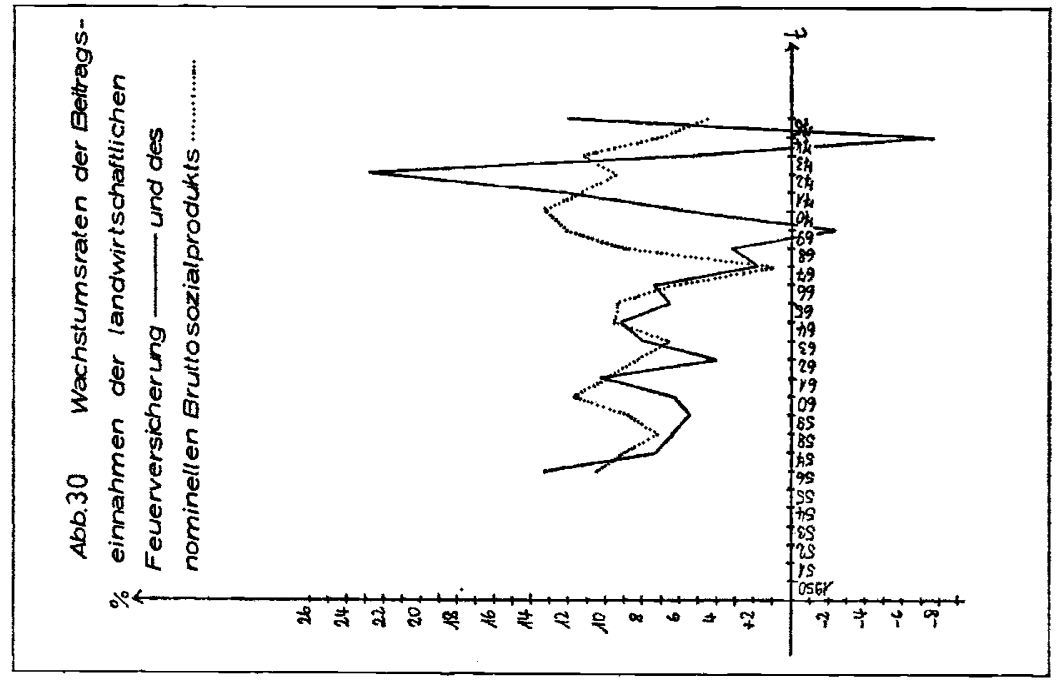

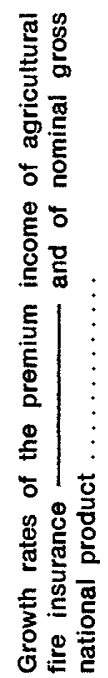
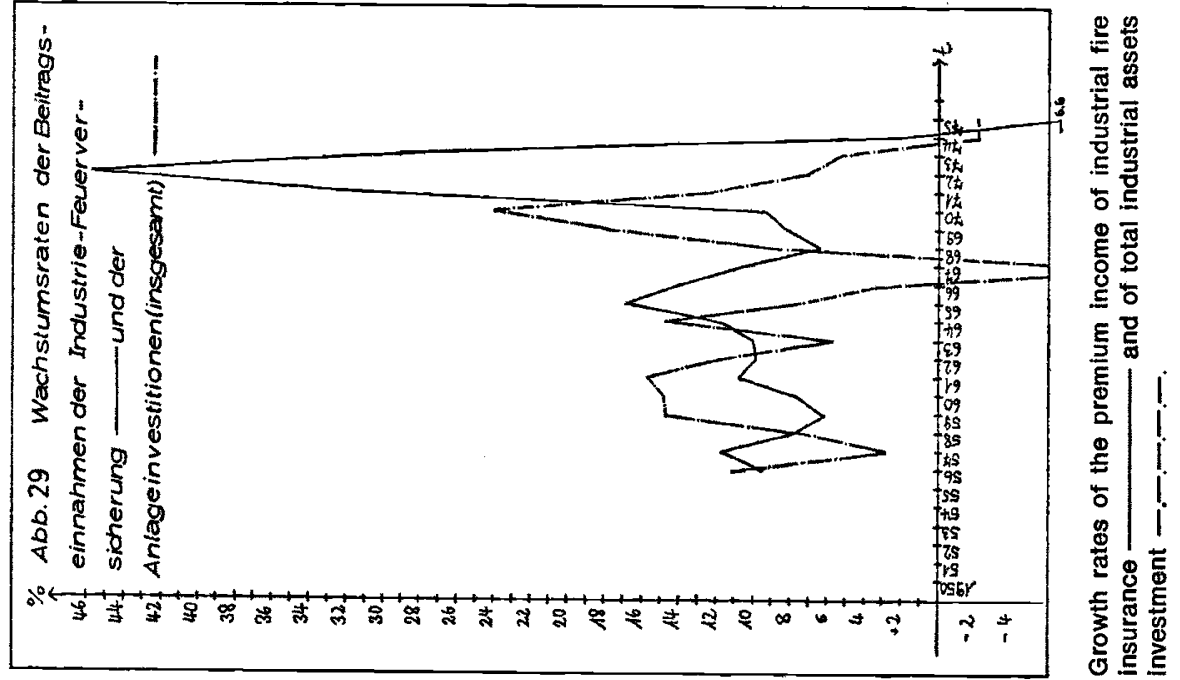

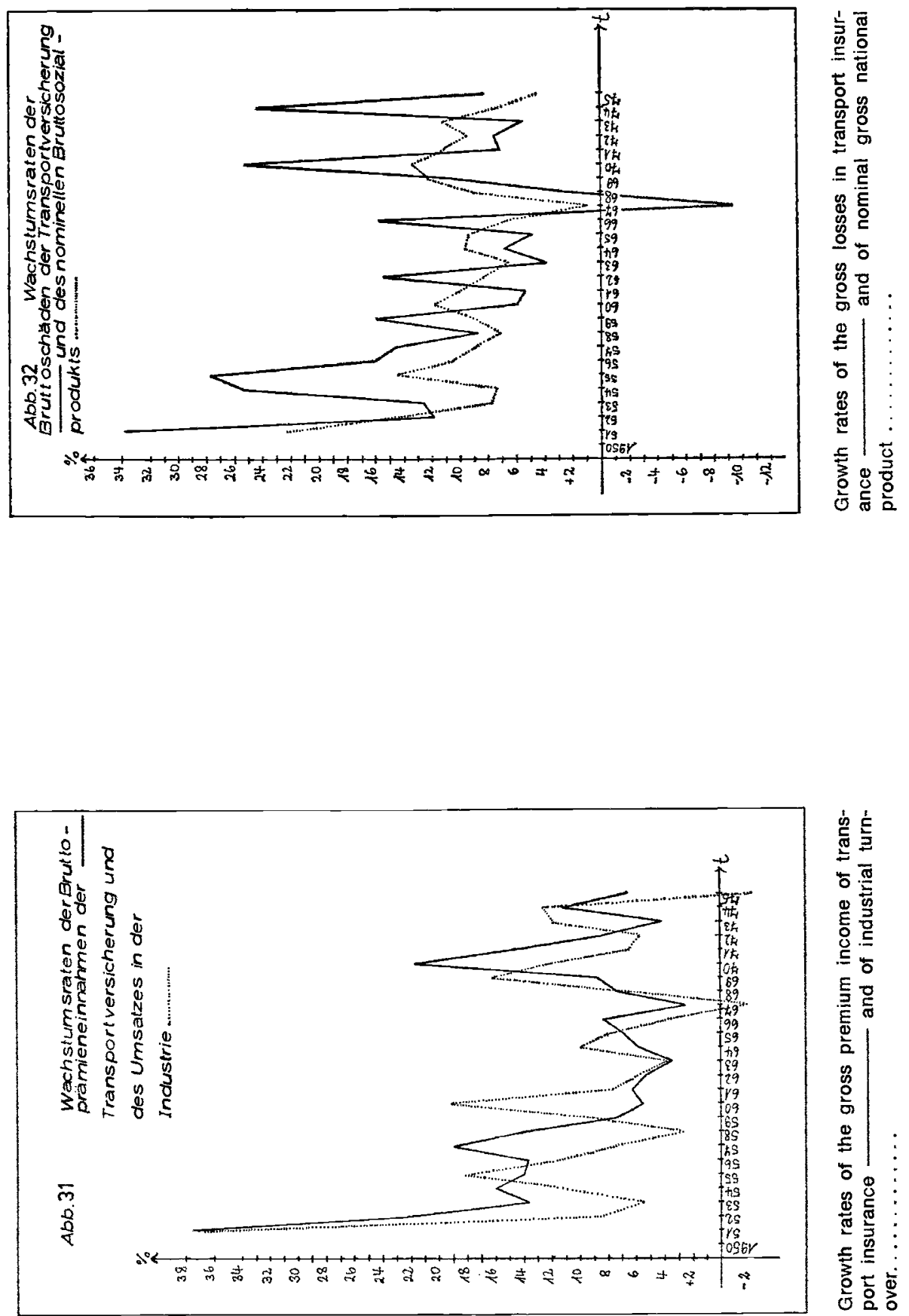


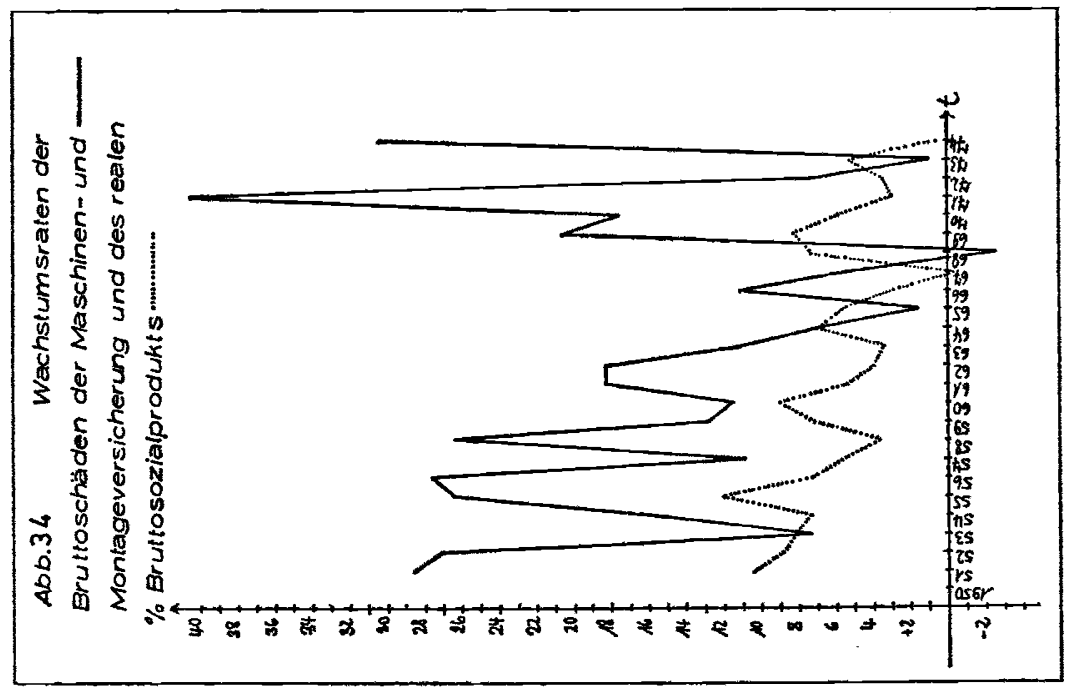

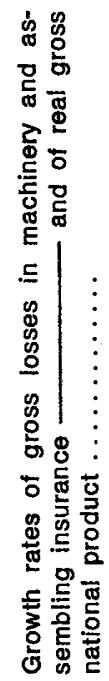
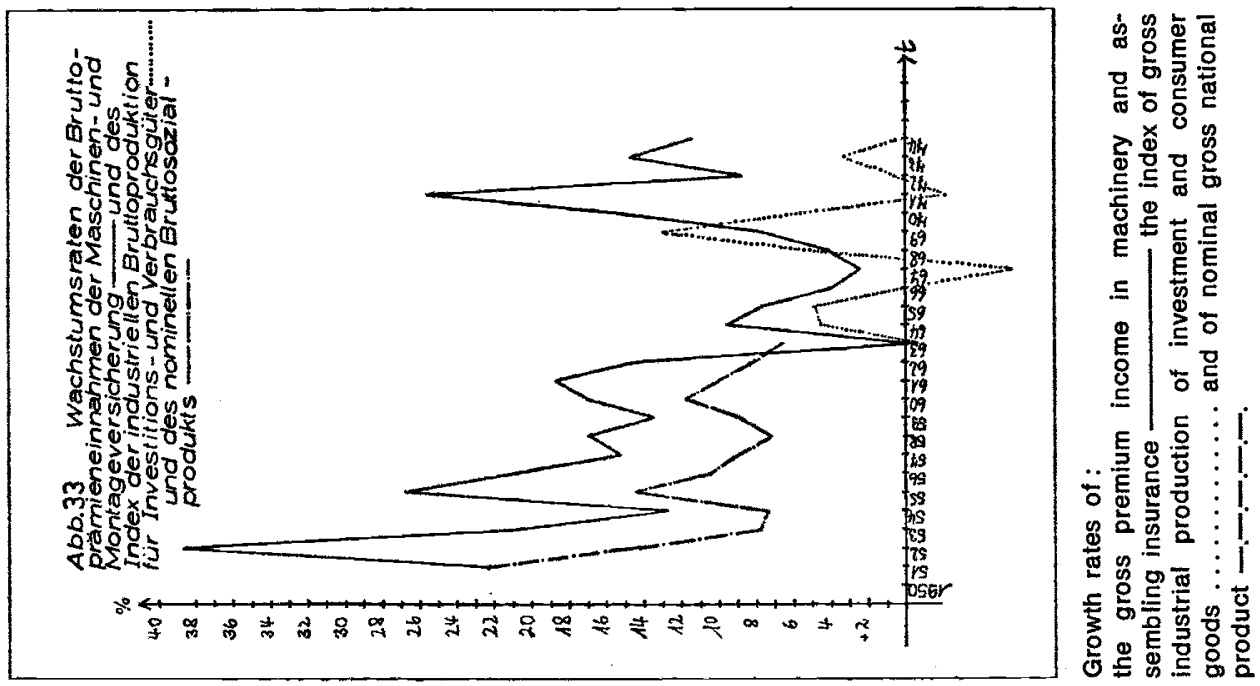